\title{
Open Market Share Repurchases and Earnings Management
}

\author{
Arturo Rodríguez \\ Facultad de Economía y Negocios \\ Universidad de Chile \\ arodriguez@unegocios.cl \\ Heng Yue \\ Guanghua School of Management \\ Peking University
}

\begin{abstract}
In this study we examine earnings management around open market share repurchases. We examine two hypotheses: managerial opportunism and market response, both of which predict that managers will manage earnings down prior to an open market repurchase. Using 2,939 repurchase announcements during 19801998 we find evidence that managers do manage earnings down before share repurchases. We also find that the market does not
\end{abstract}

We appreciate helpful comments from Vladimir Gatchev, Mark Leary, David Lesmond, Paul Spindt, and especially Venkat Subramaniam. We also thank participants of workshops at Guanghua School of Management, 2004 SWFA conference, 2004 FMA annual meeting, and 2004 AAA conference. Both authors thank Tulane University for financial support. Heng Yue acknowledges the financial support provided by NSFC (70532002). All errors remain ours. 
identify the earnings manipulation when the repurchase is announced, and that discretionary accruals can explain a significant part of long-term positive returns following repurchases. Altogether the evidence is consistent with the managerial opportunism hypothesis. Further investigation indicates that managers with higher ownership in the firm are more likely to manage earnings down.

JEL classification: G35; G14

Keywords: Open market share repurchases; Earnings management; Abnormal returns.

\section{Resumen}

En este estudio analizamos la manipulación de beneficios en torno a las recompras de acciones. En concreto, examinamos dos hipótesis: oportunismo y eficiencia. Ambas hipótesis predicen que los gerentes deben manipular los beneficios de las empresas reduciéndolos antes de anunciar una recompra pero difieren en su predicción de los efectos de dicha manipulación a largo plazo. Tras analizar una muestra de 2939 anuncios de recompra, la evidencia estadística sugiere que los gerentes reducen artificialmente los beneficios corporativos antes de recomprar acciones. También mostramos que los indicadores convencionales de manipulación de beneficios están significativamente relacionados con las rentabilidades anormales a largo plazo asociadas con las recompras lo que resulta congruente con la hipótesis del oportunismo.

Palabras clave: Recompras, manipulación de beneficios, rendimientos anormales. 


\section{Introduction}

Open market share repurchases ${ }^{1}$ have become increasingly popular in United States in recent years. In 1985, only 147 open market share repurchase programs were announced with a value of about \$16 billion, while between 1996 and 2005 U.S corporations announced repurchases of approximately $\$ 1,8$ trillion. Also, beginning from 1997, firms spent more on stock repurchases in aggregate than on cash dividends, (see Dittmar and Dittmar 2003). The surge in share repurchase activity has stimulated a considerable amount of academic research. However the extant literature has largely focused on the rationale behind this corporate event or the market reaction to it. In this study we examine whether companies manage earnings around share repurchase.

Previous research on earnings management has found evidence of earnings manipulation around different corporate events. For example, Teoh, Welch, and Wong (1998a, 1998b) found that managers manage earnings up prior to IPO and SEO, Erickson and Wang (1999) documented earnings management before stock mergers and Vafeas et al (2003) examine earnings management around tender offer repurchases and find weak evidence of biased accruals around them. Other earnings management cases include management buyout (Perry and Williams, 1994; Wu 1997), bankruptcy (Chau and Lee, 2000), option awards (Balsam, Chen, and Sankaraguruswamy 2003).

The extant literature examines two hypotheses regarding earnings management around corporate events: managerial opportunism and market response. Both hypotheses will predict

${ }^{1}$ In this paper we use share repurchase or repurchase and open market repurchase interchangeably. There are actually four ways to buyback shares: open market repurchase, tender offer repurchase, targeted repurchase (also known as "greenmail") and privately negotiated repurchase. Open market share repurchase is the most popular type among the above four types repurchase programs. See Grullon and Ikenberry (2000) for more discussions. 
earnings management in the case of a share repurchase. In the context of repurchase, according to the managerial opportunism hypothesis, managers have incentives to manage earnings down to temporarily deflate stock price so that they can buyback shares at a lower price. Buying back shares at artificially low prices results in a positive net present value investment. Therefore, it increases the long-term firm value at the expense of shareholders who sold the stocks during the repurchase. Alternatively, according to the market response hypothesis, firms manage earnings down because the market expects them to do so. When the repurchase is announced, the market immediately adjusts for managed earnings, and the repurchase price is a fair price. ${ }^{2}$ Although both hypotheses predict downward earnings management, the market reactions to the repurchase announcement are different.

To study earnings management in the periods around share repurchases, we investigate 2,939 repurchases during 1980-1998. Using the cross-sectional version of the adjusted Jones model with performance controlled to measure earnings management, we find discretionary accruals are significantly negative in the year prior to the repurchase announcement, consistent with both hypotheses. We then examine the market reaction to the announcements of share repurchases and find that the initial market reaction does not relate to the level of accruals, which suggests that the market does not see through the earnings management immediately, contrary to the market response hypothesis. We also analyze the long-horizon returns subsequent to repurchase announcements. Consistent with Ikenberry, Lakonishok, and Vermaelen (1995), after controlling for both size and book-to-market, we find that repurchase firms earn excess returns in the 4 years following the announcement of repurchase. More interesting, we find that the excess returns are mostly driven by firms with the lowest (ie. the most negative)

\footnotetext{
${ }^{2} \mathrm{We}$ will discuss these two hypotheses in more details in the hypotheses development section.
} 
discretionary accruals. Specifically, when we form portfolios on the basis of discretionary accruals, we find that firms in the most aggressive earnings management quintile (i.e., those with most negative accruals) significantly outperform their non-repurchasing matches. For 48 months following the repurchase announcement, firms in the quintile with the most negative discretionary accruals outperform their reference portfolio by a return differential of about $28 \%$. In contrast, the portfolios with the least negative discretionary accruals underperform their peers by a significant $19.9 \%$. Altogether the evidence suggests that the market is temporarily misled by earnings manipulation, consistent with the managerial opportunism hypothesis while against the market response hypothesis.

We also examined whether the managers' stake in the firms will affect the earnings management behavior. The results indicate that the more the managers' share holdings in the firm, the higher degree of the (negative) earnings management, suggesting that managers manipulate earnings for their own interests.

Our paper makes several contributions to the literature. First, it contributes to our understanding of the role of accounting earnings in open market share repurchases, thereby allowing us to gain a better understanding of this important economic event. Early studies mainly see repurchases as a corporate event that firms use to distribute free cash flow or signal favorable information. Recently, researchers have noticed that managers might opportunistically use share repurchases. ${ }^{3}$ Our study provides further evidence that managers can opportunistically manage earnings around the share repurchase. In a theoretical paper, Fischer and Verrecchia (2000) point out that managers may have incentives to manage earnings down when repurchasing stocks. Our paper, to our knowledge, is the first study that empirically relates earnings management and open

${ }^{3}$ For example, repurchase can avoid the negative effects of dividends on option value (Kahle, 2002). Also repurchase reduces outstanding shares and therefore can be used to increase earnings per shares, (see Bens, Nagar, Skinner and Wong, 2002). 
market repurchases. In addition, we explicitly test the managerial opportunism and the market response hypotheses in the repurchase setting.

Second, our findings shed new light on the long-term performance following repurchase announcements by studying the relation between earnings management and the long-run returns following buybacks. The most common explanation for the longterm performance following repurchase is market underreaction. By presenting the evidence that the long-term abnormal returns are mostly driven by those firms with the most negative discretionary accruals, we advance further the underreaction explanation, that is, the long-term abnormal returns come from the fact that managers use earnings management to temporarily mislead the stock market.

Third, Healy and Wahlen (1999) note that the widespread use of accounting information by investors and financial analysts to help value stocks could create an incentive for managers to manipulate earnings in an attempt to influence stock price performance. Therefore, the current study contributes to the literature on earnings management motivated by capital market expectations and valuation, and is very similar in spirit to the studies of earnings manipulation prior to SEO, IPO, or merger (e.g., Teoh et al., 1998a, 1998b; Erickson and Wang, 1999; Louis, 2003). We also find that discretionary accruals are related to managers' holdings in the firm, suggesting that managers act for their own interests.

The remainder of the paper is organized as follows: Section 2 reviews literature in repurchase and earnings management; Section 3 presents and develops the hypotheses; Section 4 outlines the data sources; Section 5 discusses the empirical methodology; Section 6 presents the main empirical results; Section 7 includes further investigations and Section 8 concludes the paper. 


\section{Literature review}

Because this study relates earnings management to share repurchase, we review relevant research in both fields in this section.

\section{A. Open market share repurchases}

In an open market share repurchase, a firm buys back its shares in the open market over a number of months or even years at the market price. Several features worth attention are associated with this corporate event. First, firms are not required to announce in advance their intention to repurchase their shares. Nevertheless, many of them do so. ${ }^{4}$ Second, firms are not required by law to actually buyback the number of shares that they announced they wanted to acquire. Some firms can buyback more shares than their announcement target, while others may not buyback at all. Third, it is difficult, even ex post, to get information on how many shares have been bought back and when they were bought back. However, Stephens and Weisbach (1998) propose several methods to estimate the number of shares a company actually acquired after a repurchase announcement. They find repurchase firms, on average, acquire 74 to $82 \%$ of the shares announced as repurchase targets within three years after the announcements. Most of the shares are acquired in the first year following the repurchase announcements.

Previous research has found a positive market reaction associated with the announcement of share repurchases (see Comment and Jarrell 1991; Bartov, 1991), which may indicate that a share repurchase conveys favorable information to the market.

${ }^{4}$ However, SEC Rule 10b-5, 17 C.F.R. $§ 240.10 b-5$ (1997) has been construed to require disclosure in connection with stock repurchase programs if the repurchases are "material" to the company. Whether such a program is "material" under a particular company's circumstances must be resolved in light of those circumstances by management of the company with the advice of counsel. 
Ikenberry, Lakonishok, and Vermaelen (1995) also find that repurchase firms earn positive abnormal returns up to four years following the announcement of a repurchase.

To explain the motivations of share repurchases, many hypotheses have been proposed (see Dittmar, 2000). However, the most common explanations of stock buybacks are the signaling hypothesis and free cash flow hypothesis. The signaling hypothesis suggests that managers use repurchases to convey information to the market regarding future prospects (Ikenberry, Lakonishok, and Vermaelen, 1995). On the other hand, the free cash flow hypothesis suggests that paying out cash to shareholders can reduce agency costs (see for example Nohel and Tarhan 1998). Recent studies also find that the increasing popularity of share repurchases can partly be explained by the growing use of stock options. ${ }^{5}$

\section{B. Earnings management}

The accounting literature has presented plenty of evidence that managers manipulate earnings within or beyond GAAP. In this section, we only review earnings management associated with corporate events. ${ }^{6}$ Usually in this type of study, a corporate event that provides incentives for earnings management is identified and earnings around the event announcement are subject to scrutiny.

Teoh, Welch, and Wong (1998a, 1998b) find earnings management prior to SEO or IPO. They also find that discretionary accruals in the year before SEO or IPO can be used to explain the abnormal negative returns following SEO. Shivakumar (2000)

${ }^{5}$ See for example Kahle (2002), Fenn and Liang (2001) and Weisbenner (1999). It is interesting to notice that the results in Kahle (2002) are consistent with managers acting to maximize their own wealth and therefore they indirectly support the hypotheses analyzed in this study.

${ }^{6}$ For more comprehensive review of earnings management, see Healy and Wahlen (1999). 
confirms the existence of earnings management prior to SEO. However, he shows that the motivation to manage earnings is to respond to the market beliefs. ${ }^{7}$ The market seems to expect the exact amount of managed earnings, and discretionary accruals cannot explain the long-term abnormal returns. Erickson and Wang (1999) present evidence that acquiring firms overstate earnings prior to a stock swap announcement, while no evidence of earnings manipulation exists for acquiring firms using cash for acquisition. Louis (2003) confirms the existence of earnings management around stock mergers and presents evidence that the discretionary accruals can explain abnormal negative returns following the merger. DeAngelo (1986) finds no earnings management prior to management buyout, while Perry and Williams (1994) and Wu (1997) find earnings management using a larger sample and a more refined research design. Balsam et al. (2003) find that to achieve favorable exercise prices, executives manage earnings down before the firms award options. Altogether, earnings management has been found around various corporate events.

\section{Hypotheses development}

In the section above, we briefly review literature in share repurchase and earnings management. As a corporate event, share repurchase is very similar to a management buyout. The difference is that firms buyback all the shares in a management buyout, while in a share repurchase, firms buyback only a proportion of the total number of shares outstanding. The share repurchase can also be seen as the opposite process to a SEO, where the former tends to decrease the shareholder base, while the latter usually adds in new shareholders.

${ }^{7}$ Because the market expects that managers will manage earnings upward, the best strategy for managers is to manage earnings upward. Otherwise, the price will be set lower than the actual value. 
As a point of fact, the events exhibit contrary market reactions. Given these characteristics we are surprised that no studies have explored the possibility of earnings management around share repurchases.

Similar to earnings management research around other corporate events (i.e., IPO, SEO, and stock mergers), we consider whether two hypotheses, managerial opportunism and market response, can explain the data patterns around share repurchases. These two hypotheses have been examined in other corporate events, (see for example Teoh, Welch, and Wong 1998a, 1998b and Shivakumar 2000 et al.)

\section{A. Managerial Opportunism}

The managerial opportunism hypothesis argues that managers will opportunistically manage earnings. In the case of share repurchase, managers can understate earnings before repurchase to mislead investors and temporarily deflate stock prices. Firms can then buyback shares at artificially low prices, because investors fail to understand that the managers are manipulating earnings, and, when subsequent earnings increase unexpectedly, the firms will earn abnormally positive returns. If managerial opportunism holds, earnings management will benefit those shareholders who do not sell shares at the expense of those who sell their shares.

To illustrate this hypothesis, consider a firm worth $\$ 100$ with ten shares outstanding and the need to buyback one share. Each share will have true value of $\$ 10$. Also assume the true earnings is $\$ 1$ per share and shareholders mechanistically use a P/E 10 to decide the stock price. If managers do not manage earnings and report earnings as $\$ 1$ per share, the market price is $\$ 10$ per share, which is equal to the true value, and the firm buys back at a fair price of $\$ 10$. After the repurchase, both the shareholders who sold and those who did not, receive $\$ 10$. Now suppose the managers can manipulate the 
earnings and report them as $\$ 0.5$, the stock price will be $\$ 5$. ( $\mathrm{PE}=10$, price $=0.5 * 10$ ). When the firm buys back one share, it pays out $\$ 5$. The final value of the firm will be 95 (100-5), and the value per share will be $\$ 10.56$ (95/9). The remaining shareholders will benefit while those who sold the shares lose (receive $\$ 5$ for a $\$ 10$ value of share). In this scenario, a repurchase equals a positive net present value investment because the firm can buyback shares at a price lower than true value.

Because earnings management under the managerial opportunism hypothesis will hurt the interests of some shareholders (those who will sell the shares), one may ask why managers have incentives to do it. We argue that if the managers have ownership in the firm or their compensation is tied to the long-term firm value, managers will benefit from the earnings management if they do not sell their shares. Alternatively, managers may act for the benefit of long-term shareholders, who tend to be large shareholders and have more influence on managers' compensation. Extant evidence seems consistent with the argument. Lee et al. (1992) found evidence that insiders buy more shares or sell fewer shares before tender offer share repurchase. Grinstein and Michaely (2002) find that institutional investors increase their holdings when the firm repurchase more stocks.

In addition, several studies have tested and found support for the managerial opportunism hypothesis in cases of SEO, IPO, and stock mergers (see Rangan, 1998; Teoh et al., 1998a, 1998b; Louis, 2003). Compared to SEO, IPO or a stock merger, a share repurchase is a more likely scenario to have a managerial opportunism problem. The reason is that in SEO, IPO, or stock merges, managers will hurt the interests of at least some of the future shareholders, while in a share repurchase, all future shareholders benefit. The future shareholders will determine the compensation or job security of managers and are the future owners of the firm. They are less likely to penalize managers in the case of repurchase since they receive benefits. 
To temporarily manage earnings down, managers incur some costs. One cost common to other earnings management is the possibility of being discovered. ${ }^{8}$ Another potential cost is that lower reported earnings may influence the compensation or job security in the current period. Therefore, whether the cost will deter the earnings management is an empirical question.

\section{B. Market response}

The market response hypothesis comes from Stein (1989), who develops a model of asymmetric information about firm value between the managers of the firm and the market. The equilibrium of the model is that the market is efficient and correctly anticipates earnings manipulation and adjusts for it in pricing the firm. Nonetheless, managers, in response to the market's beliefs, continue to manipulate earnings. Shivakumar (2000) examines the market response hypothesis in the context of seasoned equity offerings. He finds evidence of earnings management, but the announcement returns are related with managed earnings. He also shows that there is no relation between discretionary accruals and post-offering stock performance when using refined measurement of long term returns, supporting the market response hypothesis. Erickson and Wang (1999) suggest that earnings management around a stock merger is also consistent with the market response hypothesis, but they do not test it. Louis (2003) explicitly tests the market response hypothesis but finds no supporting evidence.

In the case of repurchase, the market response hypothesis suggests that if the market's expectation is that the managers will deflate earnings prior to repurchase, and, therefore, adjust the reported earnings upward, managers will have incentive to manage

\footnotetext{
${ }^{8}$ More discussions about the consequence of earnings management please refer to Dechow, Sloan and Sweeney (1996).
} 
earnings down. Otherwise, managers will have to buyback shares at prices higher than the true value. The logic is like the "Prisoner's Dilemma" and can be illustrated using the game:

MARKET EXPECTATION

\begin{tabular}{ll|c|c|} 
& \multicolumn{2}{c}{ No EM } & EM \\
\cline { 3 - 4 } Managers & No EM & $(0,0)$ & $(-2,1)$ \\
\cline { 3 - 3 } & EM & $(1,-2)$ & $(-1,-1)$ \\
\cline { 2 - 3 } & &
\end{tabular}

Given this game, the only Nash equilibrium is that the market expects earnings management and managers manage earnings.

\section{Discussion of hypotheses}

The difference between the managerial opportunism hypothesis and the market response hypothesis does not lie in the motivations of earnings management. First, under both hypotheses, managers of repurchase firms want to buyback shares at low prices and, therefore, manage earnings down. Second, although under the market response hypothesis managers cannot obtain extra benefits from earnings management, an appropriate amount of earnings management allows firms to buyback at true value and avoids possible losses in the repurchase process. Third, although the managerial opportunism hypothesis clearly identifies that shareholders who sell shares during the repurchase process lose money, the market response hypothesis also implies loss of some shareholders. This loss occurs because managers need time to manage earnings. Although the market can adjust prices after the repurchase announcement, in the period prior to the announcement while earnings have been managed down, the prices are different 
from the true value. Thus, investors who sell shares during that period incur loss.

The real difference between the managerial hypothesis and the market response hypothesis lies in the assumption of the degree of market efficiency. The market response hypothesis makes a strong assumption about market efficiency. It requires that the market can anticipate managed earnings once the repurchase is announced therefore the market will react to managed earnings. In contrast, managerial opportunism assumes that the market is not that efficient and can be deceived by managed earnings, and, consequently, managed earnings affect the long term returns after the repurchase announcements. By examining the abnormal returns at the repurchase announcements and the long-term returns after the announcements, we can distinguish the above two hypotheses.

\section{Data}

Data on open market repurchase announcements come from two different sources. ${ }^{9}$ The main sample comes from announcements reported in the Securities Data Corporation's U.S Mergers and Acquisitions database over the period 1985-1998. This database contains the most comprehensive sample of open market share repurchase programs available and covers most of the repurchase programs after 1984. We supplement this sample with announcements of programs reported in the Wall Street Journal

${ }^{9}$ Ideally it is more reasonable to include only firms that do buyback shares since only those firms have the incentives to manage earnings. The announcement of repurchase is not a commitment to buyback. Also firms should manage earnings before the actual buyback not the announcement. However, it is hard to know whether and when the firms buyback. Stephens and Weisbach (1998) estimate that most of firms who announce the repurchase plan do buyback shares and they buyback most of the shares in the first year. We argue that the selection of sample introduce noise which will be against to find any results. 
Index over the period 1980-1984. We include this period in the sample to compare our results with those in earlier studies (e.g., Ikenberry, Lakonishok, and Vermaelen, 1995) and to check for robustness across time periods. ${ }^{10}$

To avoid confounding effects in the detection of earnings management, we focus the analysis on repurchase initiations. An announcement is not classified as an initiation if any one of the following two criteria is met:

- $\quad$ The announcement explicitly states the firm is continuing and/or expanding a presently ongoing open market repurchase program.

- Within the three-year period preceding the announcement, the firm made a similar announcement of an open-market repurchase program.

The final sample satisfies the following criteria:

- $\quad$ A firm is present in COMPUSTAT (Full coverage, Primary, Secondary, Tertiary and Research Files), and it has sufficient data to compute discretionary accounting accruals for the year prior to the repurchase announcement. ${ }^{11}$

- Information on common stock returns is available on the Center for Research in Securities Prices (CRSP) files.

- $\quad$ The firm discloses the number or percentage of shares sought during the duration of the share repurchase program. If the firm only announces the number of shares sought, the

${ }^{10}$ Excluding observations within 1980-1984 will not affect our conclusions.

${ }^{11}$ As will see in table 5 and 6 , firms may lack necessary information in years before or after repurchase announcements. Therefore the number of observations is the largest in year -1 and decreasing in years away from year -1 . 
percentage of shares sought is calculated using the number of shares outstanding at the time of the announcement of the share repurchase program.

- The announcement of the open market share repurchase program is not made during the last quarter of 1987. Following Ikenberry, Lakonishok, and Vermaelen (1995), this period is excluded from the sample because many corporations established open market share repurchase during this period to stabilize stock prices after the market crash of October of 1987. Furthermore, during this period, many companies did not announce the number of shares authorized for repurchase.

The final sample consists of 2,939 repurchase announcements. Table 1 gives a frequency distribution by the year of announcement, which illustrates that most of the observations in the sample are concentrated in the 1990's. During the first ten years (1980-1989), we have only 857 observations (29.2\%), while in the following nine years we have 2,082 observations $(70.8 \%)$. Furthermore, the percentage of planned buyback is also increasing. In the first five years, median firms bought back only 1\%, while in 1985 the percentages increased to around $5 \%-6 \%$. This is not surprising because this period is considered to be one of the most active ever in share repurchase activity. We also notice that the percentage of firms in our final sample declines with time. The reason is that firms in the latter years tend to announce repurchase plans more frequently and our final sample includes only those that have no other repurchase plans in the previous three years. 
Table 1

Distribution of repurchase firms in years

\begin{tabular}{|c|c|c|c|c|c|c|}
\hline YEAR & $\begin{array}{r}\text { \# OF OBS. IN } \\
\text { ORIGINAL } \\
\text { REPURCHASE } \\
\text { SAMPLE }\end{array}$ & $\begin{array}{l}\text { \# } \text { OF } \text { OBS. } \\
\text { IN FINAL } \\
\text { SAMPLE }\end{array}$ & $\begin{array}{c}\text { PROPORTION } \\
\text { OF ORIGINAL } \\
\text { SAMPLE }\end{array}$ & $\begin{array}{r}\text { MEDIAN OF } \\
\% \text { OF } \\
\text { REPURCHASE }\end{array}$ & $\begin{array}{r}\text { MEAN } \\
\text { OF } \\
\text { TOTAL } \\
\text { ASSETS } \\
(\mathrm{MM \$ )}\end{array}$ & $\begin{array}{r}\text { MEDIAN } \\
\text { OF } \\
\text { TOTAL } \\
\text { ASSETS } \\
(\mathrm{MM} \$)\end{array}$ \\
\hline 1980 & 95 & 41 & $43.2 \%$ & 1.0 & 1,079 & 134 \\
\hline 1981 & 92 & 61 & $66.3 \%$ & 1.0 & 1,450 & 205 \\
\hline 1982 & 134 & 68 & $50.7 \%$ & 1.0 & 1,721 & 295 \\
\hline 1983 & 54 & 19 & $35.2 \%$ & 1.0 & 1,749 & 417 \\
\hline 1984 & 206 & 110 & $53.4 \%$ & 1.0 & 2,289 & 124 \\
\hline 1985 & 147 & 78 & $53.1 \%$ & 7.6 & 1,330 & 228 \\
\hline 1986 & 168 & 83 & $49.4 \%$ & 8.1 & 3,131 & 267 \\
\hline 1987 & 123 & 47 & $38.2 \%$ & 8.2 & 2,731 & 131 \\
\hline 1988 & 257 & 118 & $45.9 \%$ & 7.7 & 1,720 & 239 \\
\hline 1989 & 481 & 232 & $48.2 \%$ & 7.3 & 2,088 & 169 \\
\hline 1990 & 710 & 340 & $47.9 \%$ & 6.1 & 1,003 & 122 \\
\hline 1991 & 284 & 88 & $31.0 \%$ & 5.9 & 665 & 85 \\
\hline 1992 & 437 & 165 & $37.8 \%$ & 5.4 & 451 & 81 \\
\hline 1993 & 448 & 139 & $31.0 \%$ & 5.2 & 726 & 83 \\
\hline 1994 & 743 & 242 & $32.6 \%$ & 5.0 & 1,635 & 119 \\
\hline 1995 & 777 & 196 & $25.2 \%$ & 5.0 & 2,351 & 114 \\
\hline 1996 & 960 & 233 & $24.3 \%$ & 5.0 & 784 & 110 \\
\hline 1997 & 858 & 245 & $28.6 \%$ & 5.5 & 1,689 & 119 \\
\hline 1998 & 1,248 & 434 & $34.8 \%$ & 6.3 & 978 & 104 \\
\hline Mean & 432 & 155 & & & 1,556 & 166 \\
\hline Total & 8,222 & 2,939 & $35.7 \%$ & & & \\
\hline
\end{tabular}

The original repurchase sample includes all observations that have announced repurchase plan during 1980-1998 with percentage identified. The final sample requires all necessary information for calculation in year -1.Total assets are measured at the beginning of the year.

\section{Methodology}

\section{A. Estimating earnings management}

Following previous research, we use discretionary accruals from a cross-sectional Jones model as a measure of managerial discretion in reported earnings figures (see, for example, Teoh et al., 1998). For each year and two-digit SIC code category with at least ten observations, we run the following regression: 
Accrual $_{t} / A_{t-1}=\alpha_{1}\left(1 / A_{t-1}\right)+\alpha_{2}\left(\Delta \operatorname{Re} v_{t} / A_{t-1}\right)+\alpha_{3}\left(P P E_{t} / A_{t-1}\right)+\varepsilon_{t}$

where Accrual is total accruals. For observations with operating cash flows, the accruals are calculated as net income minus operating cash flows, while for those observations with no operating cash flows, they are calculated from balance sheets. ${ }^{1} \Delta$ Rev denotes the change in revenue adjusted for the change in accounts receivable. $P P E$ is gross property, plant, and equipment. Also, all variables are deflated by total assets at the beginning of the firm year (i.e., $A_{t-1}$ ). Jones model controls accruals from normal operation and depreciation. The fitted values, from the above regression, are nondiscretionary accruals and the residuals are the discretionary accruals.

While the Jones model imposes controls for contemporaneous operations, empirical assessments of this model suggest that estimated discretionary accruals are significantly influenced by a firm's contemporaneous and past performance (e.g., Dechow, Sloan, and Sweeney,1995; Kothari, Leone and Wasley 2005). To mitigate the problem, we estimate the performance adjusted Jones discretionary accrual. This measure is the difference between the Jones model discretionary accrual of sample firm and the corresponding discretionary accrual for a performance matched firm, which comes from the industry and has the closest performance to the repurchase firm.

The detailed matching procedure is as follows. At year -1, for each repurchase firm, we choose the firm from the same fourdigit SIC industry with the closest performance (measured as returns of assets). If the performance is around $90 \%-110 \%$ that of the repurchase firm, then we select the matching firm and the procedure stops. However, if the performance is beyond the range, we loosen

${ }^{1}$ The accruals are calculated as Accruals $=\Delta$ data $4-\Delta$ data $1-\Delta$ data $5+$ $\triangle$ data 44 - data14, where data\# are data items in Compustat. Collins and Hribar (2000) find that the accruals calculated directly from statement of cash flow are more precise than the balance sheet accruals. 
the definition of the industry and use a three-digit SIC. If necessary, we continue proceeding in this fashion until no appropriate controls are found. For our sample, we match most of the firms $(87.3 \%)$ in the two-digit SIC industry or stricter industry classifications.

To examine earnings management around repurchase, we mainly focus on year -1 , the year before announcement. We predict that managers will manage earnings down in the year before the repurchase announcement in order to deflate stock price. For year 0 and later, managers may still have incentives to manage earnings down since the repurchases may be executed during that period. However, because previous managed earnings may need to be written back ${ }^{13}$, the effects may be confounded.

\section{B. The relationship between returns and discretionary accruals}

To distinguish the managerial opportunism hypothesis and market response hypothesis, we also examine the relationship between returns and discretionary accruals. For short-term returns, we run the following regressions:

$$
\operatorname{CAR}_{(-1,1)}=\beta_{0}+\beta_{1} * \text { DISC }+\beta_{i} * \text { Controls }+\varepsilon_{t}
$$

where $C A R$ is cumulative abnormal returns, defined as raw returns minus market returns, from day -1 to day 1 , with day 0 defined as the repurchase announcement date. DISC is performance adjusted discretionary accruals. Also, we include other controls that previous studies have found to be related to announcement returns. PRER is the percentage of shares that the firm intends to buyback, BM is book-to-market value, and SIZE is the firm size measured as the log

${ }^{13}$ Earnings management by accounting methods can only shift earnings across time, therefore the managed earnings needs to be written back in the next period. 
of market value of the firm. If the market response hypothesis holds, then $\beta_{1}$ should be significant; while if the managerial opportunism hypothesis holds, then $\beta_{1}$ should be insignificant.

We also examine the relation between pre-announcement accruals and post-announcement long term returns. If the market response hypothesis holds, then pre-announcement accruals cannot predict post-announcement returns because the market can see through the earnings management once the announcement is made. In the contrast, managerial opportunism hypothesis predicts that the pre-announcement accruals will relate to the post-announcement returns.

We form five portfolios according to quintiles of preannouncement discretionary accruals. ${ }^{14} \mathrm{We}$ then assume an equalweighted buy-and-hold investment on all firms in each portfolio beginning in the month following the announcement and continuing for 12 months. After one year the portfolio is rebalanced, thus reducing the possibility that a small set of firms will dominate the return calculations. The multi-year total return to this investment strategy is calculated by compounding average annual returns over time.

The measurement of long-term abnormal returns is always controversial. We follow Ikenberry et al. (1995) and use a reference portfolio controlling for both size and book-to-market. To form this portfolio, all firms listed in the NYSE and ASE, which also appear in COMPUSTAT, are sorted each month into ten size portfolios that are further sorted by book-to-market into quintiles. This sorting procedure results in 50 benchmark portfolios for each month. Abnormal performance is then calculated using the appropriate size and book-to-market benchmark.

For statistical inference, we also follow Ikenberry et al (1995) and use an empirical simulation method or "bootstrap".

${ }^{14}$ As in Teoh et al. (1998a), we assume a four-month lag in the release of accounting information to avoid any look-ahead bias. 
Lyon, Barber and Tsai (1999) investigate the validity of this approach and conclude that the tests are generally well specified, and they are preferable to alternative methods such as conventional t-statistics.

The procedure is as follows: For the entire sample, we empirically estimate the null distribution of abnormal performance using the following procedure. We begin by taking each firm in the repurchase sample and randomly replacing it with another firm with the same size and book-to-market ranking at the time of the repurchase announcement. Once each firm in the original sample is replaced, we have a separate randomly formed portfolio, or pseudoportfolio. This new pseudo-portfolio has the same benchmark characteristics as the sample portfolio with one exception. Unlike the sample portfolio, the new pseudo-portfolio is formed randomly and is not conditioned on any information. Thus, under the null hypothesis of no abnormal returns, the difference between a pseudoportfolio and the sample portfolio should be insignificant. The process of generating pseudo-portfolios is repeated 1,000 times, thus generating a sample specific distribution of abnormal performance under the null hypothesis. P-values are obtained by simply comparing the abnormal performance estimated for the repurchase sample with the empirical distribution, and then calculating the percentage of abnormal returns above the sample portfolio abnormal returns.

\section{Empirical results}

\section{A. Evidence of earnings management}

Our first objective is to examine whether the repurchase firms manipulate earnings. We first examine firm performance around the announcement of a repurchase plan. Table 2 reports net income performance, cash flow from operations, and total accruals in the six 
years surrounding the year of the repurchase announcement. When looking at the unadjusted value of net income or cash flow, we see that the repurchase firms have a slight improvement before announcement and a slight deterioration after announcement. The median net income grows from 6.27 in year -3 to 6.84 in year -1 and then declines to 4.53 in year +3 , while cash flow from operations grows from 9.11 in year -3 to 9.76 in year -1 , and then declines to 8.47. The adjusted net income shows that our method controls performance at year -1 pretty well: Both mean and median of performance adjusted net income is 0 . For all years besides -1 , the performance is positive, however, suggesting that the performance at year -1 is relatively bad compared to other years.

Next, when comparing adjusted net income with adjusted cash flows, we see that adjusted net income is higher than adjusted cash flow from operations in the years $-2,-1,+2$, and +3 and lower than adjusted cash flow in the year $-1,0$ and 1 . Consequently, the difference between adjusted net income and adjusted cash flows, which by definition is accruals, for years $-1,0$, and 1 should be negative. This fact is consistent with firms managing earnings downward around share repurchase announcements. The behavior of adjusted total accruals around repurchase confirms it. In year -1 , the mean (median) of adjusted total accruals is $-1.22(-0.48)$, which is negative and significant. Also, in year 0 and year 1 , total accruals are negative although not significant, while in year $-3,-2$, and years 2 and 3 , adjusted total accruals are positive and sometimes significant. In summary, the pattern of total accruals is consistent with downward earnings management in year -1 .

Since total accruals include nondiscretionary accruals that may come from normal operations, we examine discretionary accruals around repurchase according to the previous described method. Table 3 presents the time series profile of discretionary accruals. The adjusted discretionary accruals are significantly negative in years $-1,0$, and +1 , with mean value of $-1.29,-0.81$ and -0.70 respectively. After year 1 , they rise monotonically until year 
+3. In summary, the evidence suggests that managers manipulate earnings downward in year $-1,0$ and 1 . Managers seem to manage earnings downwards until they actually buy back all intended shares, which may be one year after the announcement date. The evidence is consistent with both the market response hypothesis and the managerial opportunism hypothesis.

\section{Table 2}

Time-series profiles of asset scaled net income, cash flow from operations, total accruals in percent, from year -3 to +3 relative to the repurchase (year 0 )

\begin{tabular}{|c|c|c|c|c|c|c|c|}
\hline YEAR & -3 & -2 & -1 & $\mathbf{0}$ & 1 & 2 & 3 \\
\hline \multicolumn{8}{|c|}{ Net Income performance } \\
\hline \multicolumn{8}{|c|}{ Unadjusted } \\
\hline Mean & 5.58 & 5.92 & 7.09 & 6.2 & 3.56 & 2.89 & 3.44 \\
\hline Median & 6.27 & 6.48 & 6.84 & 5.92 & 4.82 & 4.38 & 4.53 \\
\hline $\mathrm{N}$ & 2,055 & 2,420 & 2,939 & 2,853 & 2,717 & 2,527 & 2,081 \\
\hline \multicolumn{8}{|c|}{ Performance Adjusted } \\
\hline Mean & 2.03 & 1.3 & 0 & 2.74 & 1.91 & 2.61 & 3.41 \\
\hline Median & 0.46 & 0.42 & 0 & 0.53 & 0.8 & 0.88 & 0.82 \\
\hline \multicolumn{8}{|c|}{ Cash flow from Operations } \\
\hline \multicolumn{8}{|c|}{ Unadjusted } \\
\hline Mean & 8.46 & 8.26 & 9.21 & 9.86 & 8.89 & 8.38 & 8.46 \\
\hline Median & 9.11 & 9.27 & 9.76 & 9.89 & 8.96 & 8.67 & 8.47 \\
\hline $\mathrm{N}$ & 2,055 & 2,420 & 2,939 & 2,853 & 2,717 & 2,527 & 2,081 \\
\hline \multicolumn{8}{|c|}{ Performance-matched Adjusted } \\
\hline Mean & 2.02 & 1.25 & 1.22 & 3.18 & 2.19 & 1.75 & 2.48 \\
\hline Median & 1.14 & 0.52 & 0.5 & 1.79 & 1.55 & 1.04 & 1.41 \\
\hline \multicolumn{8}{|c|}{ Total Accruals } \\
\hline \multicolumn{8}{|c|}{ Unadjusted } \\
\hline Mean & -2.88 & -2.36 & -2.13 & -3.66 & -5.33 & -5.49 & -5.01 \\
\hline Median & -3.76 & -3.44 & -3.48 & -4.05 & -4.81 & -5.00 & -4.77 \\
\hline $\mathrm{N}$ & 2,055 & 2,420 & 2,939 & 2,853 & 2,717 & 2,527 & 2,081 \\
\hline \multicolumn{8}{|c|}{ Performance Adjusted } \\
\hline Mean & 0.003 & 0.03 & $-1.22 * * *$ & -0.44 & -0.28 & 0.86 *** & $0.93 * *$ \\
\hline Median & 0.12 & 0.30 & $\mathbf{- 0 . 4 8} * * *$ & -0.10 & -0.02 & $0.20 *$ & 0.15 \\
\hline
\end{tabular}

* Statistically significant at a $1 \%$ level

** Statistically significant at a $5 \%$ level

*** Statistically significant at a $10 \%$ level

Net income, cash flow from operations and total accruals are all deflated by the total assets at the beginning of the year. Cash flow from operations is directly from statement of cash flow if available. Otherwise it is calculated as (Net income minus total accruals). Total accruals are the different between net income and cash flow. When cash flow is not available, it is calculated from balance sheets as: Accruals $=\Delta$ data $4-\Delta$ data $1-\Delta$ data $5+\Delta$ data $44-\Delta$ data 14 , where data\# are data items in Compustat. Performance adjusted values are calculated using the firm's variable value minus the matching firm' variable value. The matching procedure is described in table 4 . 


\section{Table 3}

Time-series profiles of performance adjusted discretionary accruals, in percent, from year -3 to +3 relative to the repurchase (year 0 )

\begin{tabular}{cccccccc}
\hline YEAR & $\mathbf{- 3}$ & $\mathbf{- 2}$ & $\mathbf{- 1}$ & $\mathbf{0}$ & $\mathbf{1}$ & $\mathbf{2}$ & $\mathbf{3}$ \\
\hline \multicolumn{7}{c}{ Performance Adjusted Discretionary Accruals } \\
\hline Mean & -0.46 & -0.16 & $\mathbf{- 1 . 2 9}^{* * *}$ & $\mathbf{- 0 . 8 1}^{* *}$ & $\mathbf{- 0 . 7 0}^{* *}$ & 0.24 & $\mathbf{0 . 6 3}^{*}$ \\
Median & -0.35 & 0.21 & $\mathbf{- 0 . 6 4}^{* * *}$ & $\mathbf{- 0 . 6 7}^{* * *}$ & $\mathbf{- 0 . 4 2}^{* *}$ & 0 & 0.00 \\
N & 2,055 & 2,420 & 2,939 & 2,853 & 2,717 & 2,527 & 2,081 \\
& & & & & & & \\
\hline
\end{tabular}

\footnotetext{
* Statistically significant at a $1 \%$ level

** Statistically significant at a $5 \%$ level

*** Statistically significant at a $10 \%$ level

Discretionary accruals are calculated from cross sectional Jones model. Specifically the following regressions are estimated each year and industry: Accrual $\mathrm{t}_{\mathrm{t}} / \mathrm{A}_{\mathrm{t}-1}=\alpha_{1}\left(1 / A_{\mathrm{t}-1}\right)$ $+\alpha_{2}\left(\Delta \operatorname{Re} v_{\mathrm{t}} / A_{\mathrm{t}-1}\right)+\alpha_{3}\left(P P E_{\mathrm{t}} / A_{\mathrm{t}-1}\right)+\varepsilon_{\mathrm{t}}$, where Accruals are total accruals $\Delta \operatorname{Re} v$, is change of revenue adjusted for changes of accounts receivables, $P P E$ is property, plant and equipment. Discretionary accruals are error terms in the regressions. We then calculate performance adjusted discretionary accruals by deducting the discretionary accruals of the matching firm. The matching procedure is described in table 4 . Year 0 is the year within which the firm announced the repurchase plan. We allow 4 months for firms to announce the earnings.
}

\section{A. Market response at the announcement date}

To distinguish the market response hypothesis from the managerial opportunism hypothesis, we examine the investors' response to earnings management at the announcement date. The market response hypothesis predicts that the market will immediately anticipate the managed earnings and therefore the returns will be positive and related to the earnings management. In contrast, the managerial opportunism hypothesis predicts no relationship.

Table 4 displays the results from an ordinary least squares regression of short-term returns (-1 to 1) on pre- announcement discretionary accruals. Consistent with previous results we see positive short-term returns at the announcement dates. However, the coefficient on discretionary accruals equals to 0.010 , which is insignificant and indicates that managed earnings cannot explain the 
announcement returns. This result is inconsistent with the market response hypothesis while consistent with the managerial opportunism hypothesis. We also consider other models including book-to-market, size and target percentage of shares to buyback as control variables. The intended percentage of buyback shares (PERR) and $\mathrm{BM}$ are found to be positive related to the returns, and size is negatively related to returns. However, the coefficient on discretionary accruals has not been affected and is always insignificant.

Overall, the findings are consistent with the managerial opportunism hypothesis, which predicts no correlation between returns and managed earnings.

Table 4

Short-term returns and discretionary accruals

\begin{tabular}{lrrr}
\hline & MODEL 1 & MODEL 2 & MODEL 3 \\
Intercept & 0.03 & 0.03 & 0.07 \\
& $(0.01)$ & $(0.01)$ & $(0.01)$ \\
DISC & 0.01 & 0.01 & 0.01 \\
& $(0.29)$ & $(0.33)$ & $(0.60)$ \\
Percent & & 0.10 & 0.10 \\
& & $(0.01)$ & $(0.01)$ \\
BM & & & 0.01 \\
& & & $(0.03)$ \\
SIZE & & & -0.01 \\
& & & $(0.01)$ \\
N: & 2,837 & 2,837 & 2,837 \\
\hline
\end{tabular}

The regression models are $C A R_{(-1,1)}=\beta_{0}+\beta_{1} * D I S C+\beta_{\mathrm{i}} *$ Controls $+\varepsilon_{\mathrm{t}}$, where the dependent variable is abnormal returns during $(-1,1)$ around the announcement of repurchase. Dependent variables include DISC and other control variables. DISC is performance adjusted discretionary accruals, Percent is the percentage that the firm wants to buyback, $B M$ is book to market ratio, Size is log of market value. P-values are in parentheses. 


\section{Long-term returns following repurchase announcement}

We also examine the long term returns after the repurchase announcements conditional on the extent of earnings management. Table 5 reports the long run return performance results. As a whole sample, the returns following repurchase are positive and significant, consistent with previous studies. ${ }^{15} \mathrm{We}$ then form portfolios according to the quintiles of performance adjusted discretionary accruals. Portfolio 0 is the one with the lowest discretionary accruals, while portfolio 4 is the one with the largest. The results show that a strategy consisting of buying the lowest discretionary accruals quintile earns abnormal returns of $2.5 \%$, $8.6 \%, 7.6 \%$ respectively in the three years after the announcements, while a strategy consisting of buying the highest discretionary accruals quintile earns abnormal returns of $-2.7 \%,-5.5 \%$ and $0.5 \%$ respectively in the three years after the announcements. In accumulation of four years after the announcements, the lowest quintile portfolio earns $27.8 \%$ excess returns, while for the highest quintile portfolio, the abnormal returns are $-19.9 \%$, both are statistically significant. The hedge returns from longing firms with the lowest discretionary accruals and shorting firms with the highest discretionary accruals reach $47.7 \%$ in four years after the announcements.

Combining with results about the short term returns around announcement dates, the evidence suggests that pre-announcement discretionary accruals have not been seen through at the announcement dates, in stead, they are reflected in the stock price after the announcements, leading to predictable return patterns in the following years. The evidence is consistent with the managerial opportunism hypothesis and is inconsistent with the market response hypothesis.

\footnotetext{
${ }^{15} \mathrm{We}$ do not report the returns for the whole sample. However the returns can be deducted by adding returns in each portfolio.
} 


\section{Table 5}

Long-term returns and portfolios based on discretionary accruals

\begin{tabular}{|c|c|c|c|c|c|c|c|c|c|c|c|}
\hline YEAR & GROUP & & REP & REFERENCE & DIFF & P-value & REP & REFERENCE & DIFF & P-VALue & RET(0-4) \\
\hline \multirow[t]{5}{*}{1} & 0 & 552 & 0.206 & 0.181 & 0.025 & 0.207 & & & & & \\
\hline & 1 & 553 & 0.241 & 0.184 & 0.057 & 0.029 & & & & & \\
\hline & 2 & 553 & 0.256 & 0.184 & 0.072 & 0.018 & & & & & \\
\hline & 3 & 553 & 0.207 & 0.171 & 0.036 & 0.098 & & & & & \\
\hline & 4 & 553 & 0.160 & 0.187 & -0.027 & 0.798 & Cumulative: & & & 0.052 & \\
\hline \multirow[t]{5}{*}{2} & 0 & 525 & 0.269 & 0.184 & 0.086 & 0.021 & 1.531 & 1.398 & 0.133 & 0.022 & \\
\hline & 1 & 524 & 0.213 & 0.184 & 0.029 & 0.186 & 1.506 & 1.402 & 0.104 & 0.032 & \\
\hline & 2 & 532 & 0.160 & 0.182 & -0.022 & 0.730 & 1.456 & 1.399 & 0.058 & 0.126 & \\
\hline & 3 & 523 & 0.187 & 0.189 & -0.001 & 0.481 & 1.433 & 1.392 & 0.042 & 0.204 & \\
\hline & 4 & 528 & 0.112 & 0.167 & -0.055 & 0.951 & 1.289 & 1.385 & -0.096 & 0.954 & 0.228 \\
\hline \multirow[t]{5}{*}{3} & 0 & 480 & 0.245 & 0.170 & 0.076 & 0.021 & 1.906 & 1.635 & 0.271 & 0.005 & \\
\hline & 1 & 494 & 0.196 & 0.174 & 0.022 & 0.229 & 1.802 & 1.646 & 0.155 & 0.031 & \\
\hline & 2 & 500 & 0.166 & 0.182 & -0.016 & 0.678 & 1.697 & 1.653 & 0.045 & 0.256 & \\
\hline & 3 & 494 & 0.203 & 0.174 & 0.029 & 0.191 & 1.725 & 1.634 & 0.090 & 0.118 & \\
\hline & 4 & 473 & 0.176 & 0.170 & 0.005 & 0.404 & 1.516 & 1.621 & -0.106 & 0.883 & 0.376 \\
\hline \multirow[t]{5}{*}{4} & 0 & 386 & 0.100 & 0.112 & -0.012 & 0.585 & 2.096 & 1.818 & 0.278 & 0.014 & \\
\hline & 1 & 410 & 0.174 & 0.149 & 0.024 & 0.233 & 2.114 & 1.892 & 0.222 & 0.018 & \\
\hline & 2 & 416 & 0.147 & 0.147 & -0.001 & 0.476 & 1.946 & 1.896 & 0.050 & 0.279 & \\
\hline & 3 & 397 & 0.157 & 0.153 & 0.004 & 0.430 & 1.995 & 1.884 & 0.111 & 0.149 & \\
\hline & 4 & 360 & 0.112 & 0.162 & -0.050 & 0.860 & 1.685 & 1.884 & -0.199 & 0.942 & 0.477 \\
\hline
\end{tabular}

The groups are formed according the adjusted discretionary accruals in year -1. Group 0 includes firms who are the most aggressive to manage earnings downwards, i.e. discretionary accruals are the smallest. Group 4 includes firms who have the largest discretionary accruals. The returns are calculated from the month following the repurchase and last for one year. Firms are equally weighted. At the end of the year, the portfolios are re-weight again to eliminate those firms disappeared. The left half table reports the returns in each year while the right half table reports the accumulated returns. Reference returns are average of reference of the pseudo-portfolio. P-value is derived from simulations.

\section{Further investigation and discussions}

The main beneficiaries of earnings management prior to a share repurchase are long-term shareholders. If the manager has a big stake in the firm, he will receive more benefits from the earnings management. In this section, we examine whether discretionary 
accruals are related to the level of managerial ownership. We define managerial ownership as the percentage of shares owned by managers and directors in the year before the repurchase announcement. Because the benefits of earnings management are increasing in the percentage of ownership, we predict a negative relation between discretionary accruals and managerial ownership. (Note this means managers with more ownership will manage more earnings down.)

To investigate the link between accruals and managerial ownership, we obtain ownership data from Execomp database. Because Execomp covers only big firms after 1990, our sample size is significantly reduced to 265 observations. Table 6 reports the results of estimating a variety of regression models. Model 1 regresses discretionary accruals on managers' ownership at the beginning of the year. The coefficient is -0.002 , which is significant at $5 \%$. This suggests that managers act for their own interests. The more shares the managers hold, the more earnings they will manage before the repurchase. Models 2 and 3 further control for other factors like change of performance, book-to-market ratio, debt-toequity ratio and firm size. The coefficient on ownership remains negative and significant. In summary, the regression analysis provides evidence that the extent of earnings management is related to the potential economic benefits to the managers. 
Table 6

Discretionary accruals and managers' ownership

\begin{tabular}{lrrr}
\hline & MODEL 1 & MODEL 2 & MODEL 3 \\
Intercept & -0.019 & -0.018 & 0.030 \\
& $(0.147)$ & $(0.178)$ & $(0.569)$ \\
EXSHPERCENT & -0.002 & -0.002 & -0.003 \\
& $(0.040)$ & $(0.040)$ & $(0.026)$ \\
DNI & & -0.049 & -0.058 \\
& & $(0.700)$ & $(0.643)$ \\
BM & & & 0.022 \\
& & & $(0.567)$ \\
DE & & & 0.025 \\
& & & $(0.654)$ \\
LA & & & -0.009 \\
& & & $(0.201)$ \\
N: & 265 & 265 & 265 \\
\hline
\end{tabular}

The dependent variable is performance adjusted discretionary accruals measured at the year before the repurchase announcement. EXSHPERCENT is the ratio of executive shares to total shares outstanding at the beginning of the year. DNI denotes the difference between net income at year -1 and the year before. BM is the book to market ratio. DE and LA are the debt to equity ratio and the lag of assets. P-values are in parentheses.

\section{Conclusion}

We study earnings management around open market share repurchases during 1980-1998, and examine two hypotheses: managerial opportunism hypothesis and market response hypothesis. Both of hypotheses predict earnings management prior to a share repurchase. Analyzing 2,939 open market share repurchase observations, we find strong evidence that managers manipulate earnings downward around a share repurchase announcement. Our measurement of earnings management, the performance adjusted discretionary accruals, shows negative and significant values at year $-1,0$ and 1 .

We also examine the relation between discretionary accruals and both short-term and long-term returns. We find that the shortterm market reaction is unrelated to discretionary accruals, which is inconsistent with the market response hypothesis. This finding suggests that the market is not efficient enough to identify or anticipate exactly the degree to which earnings are manipulated. On 
the other hand, we find a negative relation between long-term returns and discretionary accruals. The firms that aggressively manage earnings down, earn the largest positive abnormal returns in the four years following the repurchase announcement, while firms that do not manage earnings down earn negative abnormal returns over the same period. In sum, the evidence is consistent with the managerial opportunism hypothesis. According to this hypothesis, in the context of a share repurchase, managers manipulate earnings to buyback at a lower price and increase their own welfare, while the market fails to see through the manipulation and naively extrapolates pre-announcement earnings.

Further investigation shows that discretionary accruals are related to the economic benefits at stake for the managers. We measure the economic benefits to the managers as the percentage of managerial ownership in the repurchasing firm. Our analysis indicates that income decreasing manipulations prior to repurchase announcements are negatively related to the percentage of managerial ownership. 


\section{References}

BAGWELL, L. (1991), "Share repurchases and takeover deterrence", RAND Journal of Economics 22, pp. 72-88.

BARWELL, L, and J. SHOVEN "Share repurchases and acquisitions: An analysis of which firms participate". In Alan J. Auerbach (ed.), Corporate Takeovers: Causes and Consequences. Chicago: University of Chicago Press.

Balsam, S., H.J Chen and S. Sankaraguruswamy (2003), "Earnings Management Prior to Stock Option Grants”, Working paper.

BARBER, R., and J. LYON (1997), "Detecting long-run abnormal stock returns: the empirical power and specifications of test statistics", Journal of Financial Economics 43, pp. 341-372.

BARTOV, E. (1991), “Open-market Stock Repurchases as Signals for Earnings and Risk Changes" Journal of Accounting and Economics Vol. 14, pp. 275-294.

Bens, D.A., V. NAGAR, D. Skinner and M. Wong (2002), "Employee stock options, EPS dilution, and stock repurchases", Working paper.

Comment, R. and G. JARrell (1991), "The Relative Signaling Power of DutchAuction and Fixed-price Self-Tender Offers and Open-market Share Repurchases", Journal of Finance, vol. XLVI, pp. 1243-1271.

DeAngelo, L. (1986), “Accounting numbers as market valuation substitutes: A study of management buyouts of public stockholders", The Accounting Review.

DeCHOw, P., R. SlOAN and A. Sweeney (1996), "Causes and consequences of earnings manipulation: An analysis of firms subject to enforcement actions by the SEC", Contemporary Accounting Research, Vol. 13(1), pp. 1-36. 
Dechow, P., R. SlOAN and A. SWEENEY (1995), "Detecting earnings management", The Accounting Review 70, pp. 193-225.

DitTMAR, A. (2000), "Why do firms repurchase stock?), Journal of Business 73, pp. 321-356.

DitTMAR, A.K. and R. DitTMAR (2002), "Stock Repurchase Wave: An Explanation of the Trends in Aggregate Corporate Payout Policy", Working paper.

ERICHSON, M. and S. WANG (1999), "Earnings management by acquiring firms in stock for stock mergers", Journal of Accounting and Economics 27, pp. 149-176.

FENN, G. and N. LIANG (2001), "Corporate payout policy and managerial stock incentives", Journal of Financial Ecomomics 60, pp. 45-72.

Fischer, P. and R. VerReCCHIA (2000), "Reporting Bias", The Accounting Review, 75, pp. 229-245.

GrinsteIn, Y. and R. Michaely (2002), "Institutional Holdings and Payout Policy”, Working Paper, Cornell University, Ithaca, NY.

Grullon, G. and D. IKEnBERry (2000, "What do we know about stock repurchase?”, Journal of Applied Corporate Finance, 13, pp. 31-51.

HeAly, P. and J. WAHLEN (1999), "A review of the earnings management literature and its implications for standard setting", Accounting Horizons, Vol. 13, No. 4, Dec, pp. 365-383.

Hribar, P. and D. Collins (2002), "Errors in Estimating Accruals: Implications for Empirical Research”, Journal of Accounting Research 40, pp. 105-135.

IKENBERRY, D., J. LAKONISHOK and T. VERMAELEN (1995), "Market underreaction to open market share repurchases", Journal of Financial Economics 39, pp. 181-208. 
JOLLS, C. (1996), "The role of compensation in explaining the stock repurchase puzzle". Working paper, Cambridge, Mass.: Harvard Law School.

KAHLE, K.M. (2002), “When a buy-back isn't a buyback: Open-market repurchases and employee options", Journal of Financial Economics 63 (2), pp. 235-261.

Kothari, S.P., A.J. LeOne and C.E. Wasley (2005), "Performance Matched Discretionary Accrual Measure", Journal of Accounting and Economics (39), pp. 163-197.

Lee, D., W. Mikkelson and M. PARTCh (1992), "Managers' Trading Around Stock Repurchases", The Journal of Finance, Vol. 47, No 5. pp. 947-1961.

LouIS, H. (2003), "Earnings Management and the Market Performance of Acquiring Firms", Working paper.

LYON, J., B. BARBER and C. TSAI (1999), "Improved methods for tests of long-run abnormal stock returns", The Journal of Finance, Vol LIV, Nº1, pp. 165201 .

NOHEL, T. and V. TARHAN, (1998), "Share Repurchases and Firm Performance: New Evidence on the Agency Costs of Free Cash Flow", Journal of Financial Economics, Vol. 49, pp. 187-222.

OPler, T, and T. SHERIDAN (1998), "The debt-equity choice: An analysis of issuing firms", Working paper, Columbus: Ohio State University.

PERry, S., and T. Williams (1994), "Earnings management preceding management buyout offers", Journal of Accounting and Economics 18, 1994, pp. 157-179.

RAGAN, S. (1998), "Earnings before seasoned equity offerings: Are they overstated?", Journal of Financial Economics 50, pp. 101-122. 
SHIVAKUMAR, L. (2000), "Do firms mislead investors by overstating earnings around seasoned equity offerings?", Journal of Accounting and Economics 29, pp. 339-371.

STEIN, J. (1989), "Efficient capital markets, inefficient firms: a model of myopic corporate behavior", Quarterly Journal of Economics 50, pp. 63-100.

StePhens, C. and M. WeISBACH (1998), "Actual Share Reacquisitions in Openmarket Repurchase Programs”, Journal of Finance, Vol. LIII, pp. 313-333.

TEOH, S., I, WelCH and T. WONG (1998a), "Earnings management and the posissue underperformance of seasoned equity offerings", Journal of Financial Economics 50, pp. 63-100.

TEOH, S., L. WelCH and T. Wong (1998b). "Earnings management and the longrun underperformance of initial public equity offerings", Journal of Finance 53, pp. 1935-1974.

VAfeas, N., A. Vlitis, P. Katranis and K. OCKree (2003), "Earnings management around share repurchases: A note”, Abacus 39, pp. 262-271.

WU, Y.W. (1997), “Management Buyouts and Earnings Management”, Journal of accounting, auditing and finance, Vol. 12, $\mathrm{N}^{\mathrm{o}} 2$. 